\title{
Nursing Students' Perception toward Teacher-Student Relationship and its Effect on their Academic Satisfaction
}

\author{
Heba Shaban Ahmed Ibrahim1, Nermin Mohammed Eid ${ }^{2}$ and Ebtesam Saeed Ahmed
}

(1)B.Sc. Nursing Tanta University (2011) (2) Professor of Nursing Administration, Faculty of Nursing, Menoufia University (3) Assistant Professor of Nursing Administration, Faculty of Nursing, Benha University

\begin{abstract}
Background: Good and supportive teacher-student relationship is needed to create safe environments and give students confidence to work without pressure, feel more secure, competent, and eventually lead to high academic satisfaction. The study aimed to assess nursing students' perception toward teacher- student relationship and its effect on their academic satisfaction. Study design: Descriptive correlational design was utilized to conduct this study. Study setting: The study was conducted at Faculty of Nursing, Benha University. Study subjects: Included simple random sample from all undergraduate nursing students 309 out from 1355 enrolled in $2^{\text {nd }}, 3^{\text {rd }}, 4^{\text {th }}$ years at $2019 / 2020$ in Benha Faculty of Nursing. Tools of data collection: Consisted of two tools: (1):- Teacher-student relationship questionnaire and (II) Revised Undergraduate Nursing Students' Academic Satisfaction Scale (UNSASS). Results: $81.6 \%$ of studied nursing students' had a high perceived level, while the $2.5 \%$ of them had low perceived level toward teacher- student relationship among nursing students. 71.2\% of studied nursing students had high satisfaction level, while $7.1 \%$ of them had low academic satisfaction level among studied nursing students toward teacher- student relationship. Conclusion: There was a highly statistically significant positive correlation between teacher-student relationship score and total academic satisfaction score. Recommendation: The faculty administration should be developed classroom to facilitate and empower learning environment. Also, nursing teacher implemented incentive system for nursing students' progress at appropriate time.
\end{abstract}

Key words: Academic satisfaction, nursing students and teacher-student relationship.

\section{Introduction}

Teachers need to establish a relationship with their students which engender trust, respect, and an understanding of them as learners. Today the purpose of the teacher is not just to deliver lectures and give exams, but also the teacher takes on the role of organizing, managing, counseling, observing and evaluating. In order to be successful in his goals and objectives the teacher has to involve the student through commitment by developing an association with the student (Hussain, Nawaz, Nasir, Kiani and Hussain, 2013).

Teacher is the most important element in education and teaching activities. Usually a teacher is a person working in an educational institute facilitates the students to achieve cognitive, sensory and behavioral aim and gains within the range determined by the educational system. Traditionally teacher-student relationships were based on usual traditional thinking that the teachers have the basic authority and know what is best for students; 


\section{$\underline{\text { Nursing Students' Perception toward Teacher-Student Relationship and its Effect on their }}$}

Academic Satisfaction

students were viewed as inactive recipients of knowledge who always say yes to academic demands without questioning (Lyngdoh, 2017).

Relationships are defined by strong, frequent, and diverse interdependence that lasts over a considerable period of time. Teacherstudent relationship is defined as a bond that may or may not enable students to feel safe and secure in their learning environment. Also, it means strong caring and authentic relationships between teachers and students (Roberson, 2014).

Teacher-student relationships promote a sense of college belonging and encourage students to participate cooperatively. Students develop confidence to experiment and succeed in an environment where they are not restricted by the fear of failure. Teachers are able to assist students with motivation and goal setting, and students can turn to them for advice and guidance (Varga, 2017).

The effect of teacher- student relationship on nursing student is academic satisfaction. As students who receive ample support and attention from their teachers show increased academic satisfaction and achievement; students, who perceived their teachers as being friendly, also showed increased levels of academic satisfaction and involvement in extracurricular activities this helps students build positive relationships with their colleges and increases student satisfaction (Telef, Arslan, Mert and Kalafat, 2015).
Satisfaction is defined as an overall customer attitude towards a service provider, or an emotional reaction to the difference between what customers anticipate and what they receive, regarding the fulfillment of some needs, goals or desire (Singh and Badugu, 2017). Academic satisfaction is defined as a psychological state that results from the confirmation or not of the students' expectations regarding their academic reality (Hirsch, Barlem and Mendes, 2015).

In the context of nursing, it is essential to understand how students experience their undergraduate course, since feelings of suffering and stress can be identified by students who are dissatisfied, which can affect their academic lives, their professional future, their working environment and relationships, as well as people with whom they interact and the care services they will provide. In this sense, undergraduate nursing students' academic satisfaction is essential and can serve as an instrument of institutional effectiveness and success (Khawaji, Tessema and Nordin, 2016).

Recognizing the importance of student satisfaction in higher education also means making appropriate investments into facilities and intangible social structures that promote student wellbeing and a sense of belonging. Although this may sound idealistic or impractical in today's results-driven world, you should consider the effects such investment choices produce and realize that every pound you put into student satisfaction produces concrete returns (Cheng, 2016). 
Heba Shaban Ahmed Ibrahim, Nermin Mohammed Eid and Ebtesam Saeed Ahmed

\section{Significance of the study:}

Effective teachers can change the lives of their students through developing productive relationship with students. Relationship between teachers and students is the heart of learning and most teachers know this. A good and supportive teacher-student relationship is needed to create safe environments and give students confidence to work without pressure, feel more secure, competent and become motivated to learn and eventually lead to high academic satisfaction (Resis, 2015).

Students' satisfaction helps universities to make the curriculum more responsive to the needs of current atmosphere of higher education marketplace and it is a positive and significant predicator of student loyalty. Undergraduate nursing students' academic satisfaction is essential and can serve as an instrument of assessment of institutional effectiveness and success, therefore it is one of the most important factors affecting quality of university performance (Ramos, Barlem,

\section{Lunardi, and Bordignon, 2015).}

From my clinical experience, I observed that the effective teachers can meet the need of students through treating students with respect and dignity, providing students with regular feedback on their performance and energy to do any work, giving students fundamentals skill needed to be successful, listening to students carefully and encouraging students to take greater responsibility for their own learning that will reflect on abilities of students to receive information, interacting and performing well with their colleagues, better academic achievement and absorption, regular attendance and not escape from class, effective discipline in class and improving student attitude toward classwork. Teacher- student relationship is pivotal for nursing students' learning. So, this study was conducted to assess nursing students' perception toward teacher-student relationship and its effect on their academic satisfaction at Benha University.

\section{Aim of the study}

The study aimed to assess nursing students' perception toward teacher- student relationship and its effect on their academic satisfaction.

\section{Research Questions}

1-What are the nursing students' perception levels toward teacher- student relationship?

2-What are the levels of academic satisfaction among nursing students'?

3-What is the effect of nursing students' perception levels toward teacherstudent relationship on their academic satisfaction?

\section{Subjects and method}

\section{Study design:}

A descriptive correlational design was utilized to conduct this study.

\section{Study setting:}

The current study was conducted at Faculty of Nursing, Benha University which was established in 1992 and accredited on 25/8/2014 by the National Authority for Quality Assurance and Accreditation of Education (NAQAAE) and the fourth accredited Nursing Faculty between nursing faculties in Egypt. It composed of four floors and there are six scientific departments in the Faculty including; Medical and surgical nursing, Maternal and newborn health nursing, Pediatric nursing, 


\section{Academic Satisfaction}

Psychiatric and mental health nursing, Community health nursing and Nursing administration department. Also, it included: Quality assurance unit, information technology unit, strategic planning unit, unit of measurement and evaluation, research and scientific publishing unit, crisis and disaster unit, graduates unit, public services center, community service unit, and psychological counseling unit.

\section{Study subjects:}

The subjects of the present study included; Simple random sample from all undergraduate nursing students 309 out from 1355 who enrolled in $2^{\text {nd }}, 3^{\text {rd }}$ and $4^{\text {th }}$ academic years at 2019/2020 at Benha

Faculty of Nursing and $\mathrm{n}=\frac{\mathrm{N}}{\mathrm{l}+\mathrm{N}(\mathrm{e})^{2}}$ calculated according to the scientific formula:

Where " $n$ " is sample size $=309$

"N" is total number of nursing students' who accepted to participate in the current study and available at the time of data collection $=1355$

"e" is coefficient factor $=0.05 \%$ according to (Yamane, 1976).

Table (A): Distribution of studied nursing students' according to their academic year $(n=309)$.

\begin{tabular}{|l|l|}
\hline Academic year & Number of nursing students \\
\hline Second year & 101 \\
\hline Third year & 103 \\
\hline Fourth year & 105 \\
\hline
\end{tabular}

Tools of data collection:

Data were gathered by using the following two tools:
Tool (1): Teacher-student relationship questionnaire It consisted of two parts:

Part (1): Included demographic characteristics of the studied undergraduate nursing student age, gender, residence, marital status, academic year of education and estimation.

Part (2): It was adopted from Abd Elsamed, (1999) to assess nursing students' perception toward teacher-student relationship and modified by the researcher to suit the nature of the study as excluded some items as; nursing teacher attends clinical conference and scientific meetings, has planning and organizing ability and follows classroom activities. It included 37 items grouped under five domains as;

Table (B): Domains of nursing students' perception toward teacher-student relationship

\begin{tabular}{|l|l|l|}
\hline Domains & $\begin{array}{l}\text { No } \\
\text { of } \\
\text { items }\end{array}$ & Example \\
\hline $\begin{array}{l}\text { Personal attributes } \\
\text { of teacher }\end{array}$ & 10 & Accepts criticism \\
\hline $\begin{array}{l}\text { Nursing of } \\
\text { competency } \\
\text { teacher }\end{array}$ & 5 & $\begin{array}{l}\text { Likes nursing } \\
\text { profession }\end{array}$ \\
\hline $\begin{array}{l}\text { Professional } \\
\text { teaching attributes } \\
\text { in clinical setting } \\
\text { for teacher }\end{array}$ & 8 & $\begin{array}{l}\text { Possesses } \\
\text { knowledge and } \\
\text { skills required for } \\
\text { training nursing } \\
\text { students clinically }\end{array}$ \\
\hline $\begin{array}{l}\text { Teaching for } \\
\text { classroom } \\
\text { teacher }\end{array}$ & 8 & $\begin{array}{l}\text { Adapt with a } \\
\text { available facilities } \\
\text { in the classroom }\end{array}$ \\
\hline $\begin{array}{l}\text { Interpersonal for } \\
\text { relationships for } \\
\text { teacher }\end{array}$ & 6 & $\begin{array}{l}\text { Deals with } \\
\text { nursing students' } \\
\text { honestly }\end{array}$ \\
\hline Total & \multicolumn{2}{|l|}{37} \\
\hline
\end{tabular}


Heba Shaban Ahmed Ibrahim, Nermin Mohammed Eid and Ebtesam Saeed Ahmed

\section{Scoring system:}

The studied nursing students' responses were evaluated by using a three point Likert scale ranged from (1-3) as; (3) agree, (2) neutral and (1) disagree. Each studied nursing students' chosen only one answer after reading and understanding carefully. Finally the scores of each items summed up and converted to percent scores. Range of scores from (37-111) and cut point was done at $60 \%=66$ point. Accordingly, levels of nursing students' perception toward teacher- student relationship was categorized as the following; high perceived level if the percent $>75 \%$ that equal to $>83$ point, moderate perceived level if the percent from $60-<75 \%$ that equal from $66-<$ 83 point and low perceived level if the percent $<60 \%$ that equal to < 66 point (Mahdy and Mahfouz, 2016).

\section{Tool (2): Revised Undergraduate Nursing} Students' Academic Satisfaction Scale (UNSASS)

It was adopted from Dennison, (2010) to assess undergraduate nursing students' academic satisfaction level and modified by the researcher to suit the nature of the study as excluded some items as; program enhances the analytical skills and nursing teacher behave professionally. It included 28 items grouped under four main categories as;

Table (C): Categories of academic satisfaction among undergraduate studied nursing students'

\begin{tabular}{|l|l|l|}
\hline Categories & $\begin{array}{l}\text { Number } \\
\text { of items }\end{array}$ & Example \\
\hline $\begin{array}{l}\text { Clinical teaching } \\
\text { for teacher }\end{array}$ & 8 & $\begin{array}{l}\text { Views mistakes } \\
\text { as a part of the } \\
\text { learning }\end{array}$ \\
\hline
\end{tabular}

\begin{tabular}{|l|l|l|}
\hline $\begin{array}{l}\text { In-class teaching } \\
\text { for teacher }\end{array}$ & 9 & $\begin{array}{l}\text { Is easily } \\
\text { approachable }\end{array}$ \\
\hline $\begin{array}{l}\text { Program design } \\
\text { and delivery }\end{array}$ & 6 & $\begin{array}{l}\text { Provides a } \\
\text { variety of good } \\
\text { and relevant } \\
\text { courses }\end{array}$ \\
\hline $\begin{array}{l}\text { Faculty support } \\
\text { and resources }\end{array}$ & 5 & $\begin{array}{l}\text { Develops } \\
\text { classrooms to } \\
\text { facilitate } \\
\text { learning }\end{array}$ \\
\hline Total & \multicolumn{2}{|l}{28} \\
\hline
\end{tabular}

\section{Scoring system:}

The studied nursing students' responses were rated by using a three point Likert scale ranged from (1-3) as; (3) agree, (2) neutral and (1) disagree. Each studied nursing students' chosen only one answer after reading and understanding carefully. Finally the scores of each items summed up and converted to percent scores. Range of scores from (28-84) and cut point was done at $60 \%=50$ point. So, the levels of academic satisfaction among nursing students were categorized as the following; high satisfaction level if the percent is $>75 \%$ of total score that equal to $>63$ point, moderate satisfaction level if the percent from $60-<75 \%$ that equal from 50- $<63$ point and low satisfaction level if the percent $<60 \%$ of the total score that equal $<50$ point (Mahdy and Mahfouz, 2016).

\section{Ethical considerations:}

The study was conducted with careful attention to ethical standards of research and rights of the participants. Nursing students were assured that all gathered data was used for research purposes only and the study was harmless. Additionally, nursing students allow 


\section{Nursing Students' Perception toward Teacher-Student Relationship and its Effect on their}

Academic Satisfaction

to withdraw from the study at any time without giving reason and confidentially of the gathered data and results were secured. To ensure scientific honesty, the researcher used bracketing and intuiting to avoid bias.

\section{Content validity:}

Tools of data collection were translated into Arabic and investigated for their content validity by jury of five Experts from Nursing Administration. Five Assistant Professors (one from Menoufia University, one from Benha University and three from Tanta University). Who selected to test the content validity of the tools and to judge its clarity, comprehensiveness, relevance simplicity and accuracy. All of their remarks were taken into consideration and some items were rephrased to arrive at the final version of the tools. The tools were regarded as valid from the experts' point of view. It took one month September, 2019.

\section{Reliability of the tools:}

Reliability of the tools was applied by using by Cronbach's Alpha coefficient test. This turned to be $\alpha=.861$ for teacher-student relationship questionnaire and for undergraduate nursing students' academic satisfaction scale was equal $\alpha=$. 850. This indicates a high degree of reliability for the study tools.

\section{Pilot study:}

A pilot study was conducted to test the sequence of items feasibility, practicability and applicability of the tools, clarity of the language and to estimate the time needed for filling each tool. It was done on $10 \%$ of the total nursing students' that means done on nursing students'
30 there was no change occurred of the pilot study so this sample was included in the study.

\section{Field work:}

Each nursing students was interviewed after explaining the purpose of the study and getting agreement from them to participate in the study. Collection of data took two months from the beginning of November, 2019 to the end of December, 2019 after securing necessary permission.

(1) The researcher collected data from nursing students for three days per week (Sunday, Monday and Wednesday) from 9.0 a.m to 2.00 p.m.

(2) The appropriate time of data collection was after clinical training of nursing students and before starting lectures.

(3) The researcher distributes the data collection tools during available work time while not interfere with their duties and gave instruction about how the participants fill the tools and presented with them for clarification.

(4) The average time needed to complete teacher- student relationship questionnaire ranged from 30-35 minutes and for nursing students' academic satisfaction scale ranged from 20-25 minutes, the filled forms were revised to check their completeness to avoid any missing data.

(5) The average filled the tools were between 12- 13 nursing students' per day.

\section{Statistical analysis}

The collected data organized, tabulated and statistically analyzed using statistical 
package for social science (SPSS) version 21 for windows, running on IBM compatible computer. Descriptive statistics were applied (e.g frequency, percentage, mean and standard deviation. Test of significance, Chi-square test and Fisher exact test "FET" was used to detect the relation between variables. In addition, correlation coefficient (r) test was used to estimate the closeness association between variables. The $\mathrm{P}$-value is the probability that an observed difference is due to chance and not a true difference. A significant level value was considered when p-value $<0.05$ and a highly significant level value was considered when $\mathrm{p}$ value $<0.001$, while $p$-value $>0.05$ indicates non- significant results.

\section{Results}

Table (1): Illustrates that, more than half $(54.1 \%)$ of studied nursing students' were aged from 19 to 20 years old. As far as their gender and residence about three quarters (75.1\%\&71.8) of studied nursing students were female and from rural area respectively. As far as their marital status, the vast majority (91.9\%) of studied nursing students were single. According to their academic year of education and previous estimation, about nearly two fifth $(34.0 \% \& 44.3 \%)$ of studied nursing students from fourth year, and had previous estimation were very good respectively.

Figure (1): Indicates that, the majority $(81.6 \%)$ of studied nursing students had high perceived level, while the lowest percentage $(2.5 \%)$ of them had low perceived level toward teacher- student relationship among nursing students.

Table (2) that the total mean scores for all domains of teacher-student relationship was $93.59 \pm 10.26$ and the first ranking with highest mean score was $13.74 \pm 1.64$ related to nursing competency of teacher while, the last ranking with lowest mean score was $19.95 \pm 3.11$ regarding teaching in classroom for teacher.

Figure (2): Indicates that, nearly three quarters $(71.2 \%)$ of studied nursing students had high satisfaction level, while the lowest percentage $(7.1 \%)$ of them had low academic satisfaction level among studied nursing students' toward teacher- student relationship.

Table (3): Displays that, total mean scores of academic satisfaction categories was $68.39 \pm 10.23$ and the first ranking with highest mean score was $20.36 \pm 3.25$ regarding clinical teaching for teacher, while the last ranking with lowest mean score was $11.34 \pm 2.79$ related to faculty support and resources.

Table (4) shows that there was a highly statistically significant positive correlation between total perception levels toward teacherstudent relationship score and total academic satisfaction $(\mathrm{p}<0.00)$ among nursing students'. 


\section{Academic Satisfaction}

Table (1): Distribution of the studied nursing students regarding their demographic characteristics $(n=309)$

\begin{tabular}{|c|c|c|}
\hline Demographic characteristics & No. & $\%$ \\
\hline \multicolumn{3}{|l|}{ Age ( years) } \\
\hline $19-20$ & 167 & 54.1 \\
\hline $21-22$ & 137 & 44.3 \\
\hline$>23$ & 5 & 1.6 \\
\hline \multicolumn{3}{|l|}{ Gender } \\
\hline $\begin{array}{l}\text { Male } \\
\text { Female }\end{array}$ & $\begin{array}{l}77 \\
232 \\
\end{array}$ & $\begin{array}{l}24.9 \\
75.1\end{array}$ \\
\hline \multicolumn{3}{|l|}{ Residence } \\
\hline $\begin{array}{l}\text { Rural } \\
\text { Urban }\end{array}$ & $\begin{array}{l}222 \\
87 \\
\end{array}$ & $\begin{array}{l}71.8 \\
28.2 \\
\end{array}$ \\
\hline \multicolumn{3}{|l|}{ Marital status } \\
\hline $\begin{array}{l}\text { Single } \\
\text { Married }\end{array}$ & $\begin{array}{l}284 \\
25\end{array}$ & $\begin{array}{l}91.9 \\
8.1\end{array}$ \\
\hline $\begin{array}{l}\text { Academic year of education } \\
2^{\text {nd }} \text { year } \\
3^{\text {rd }} \text { year } \\
4^{\text {th }} \text { year }\end{array}$ & $\begin{array}{l}101 \\
103 \\
105 \\
\end{array}$ & $\begin{array}{l}32.7 \\
33.3 \\
34.0 \\
\end{array}$ \\
\hline \multicolumn{3}{|l|}{ Previous estimation.... } \\
\hline $\begin{array}{l}\text { Excellent } \\
\text { Very good } \\
\text { Good } \\
\text { Acceptable } \\
\end{array}$ & $\begin{array}{l}123 \\
137 \\
37 \\
12 \\
\end{array}$ & $\begin{array}{l}39.8 \\
44.3 \\
12.0 \\
3.9 \\
\end{array}$ \\
\hline
\end{tabular}

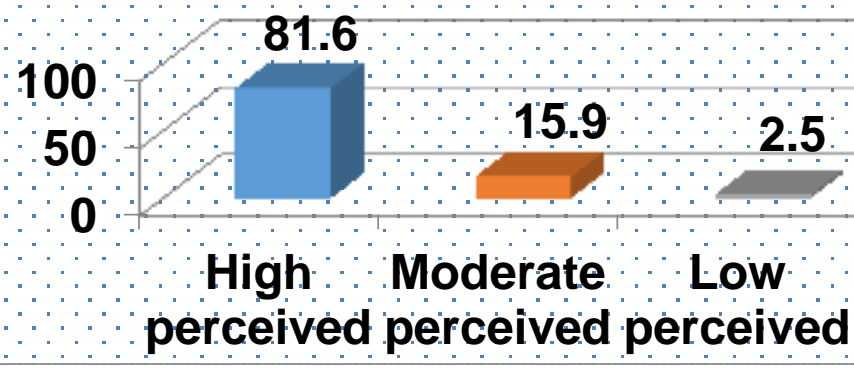

Figure (1): Total perception levels toward teacher-student relationship among studied nursing students 
Table (2): Ranking with mean scores and standard deviation of teacher-student relationship domains among nursing students $(n=309)$

\begin{tabular}{|l|l|l|l|l|l|}
\hline $\begin{array}{l}\text { Domains of teacher-student } \\
\text { relationship }\end{array}$ & $\begin{array}{l}\text { Maximum } \\
\text { score }\end{array}$ & Range & Mean \pm SD & Mean \% & Ranking \\
\hline Personal attributes of teacher & 30 & $14-30$ & $25.49 \pm 3.59$ & 84.9 & 2 \\
\hline $\begin{array}{l}\text { Nursing competency of } \\
\text { teacher }\end{array}$ & 15 & $7-15$ & $13.74 \pm 1.64$ & 91.6 & 1 \\
\hline $\begin{array}{l}\text { Professional teaching } \\
\text { attributes in clinical setting for } \\
\text { teacher }\end{array}$ & 24 & $9-24$ & $20.23 \pm 2.91$ & 84.3 & 3 \\
\hline $\begin{array}{l}\text { Teaching in classroom for } \\
\text { teacher }\end{array}$ & 24 & $11-24$ & $19.95 \pm 3.11$ & 83.1 & 5 \\
\hline $\begin{array}{l}\text { Interpersonal relationships for } \\
\text { teacher }\end{array}$ & 18 & $7-18$ & $15.08 \pm 2.37$ & 83.8 & 4 \\
\hline Total & 111 & $60-108$ & $93.59 \pm 10.26$ & & \\
\hline
\end{tabular}

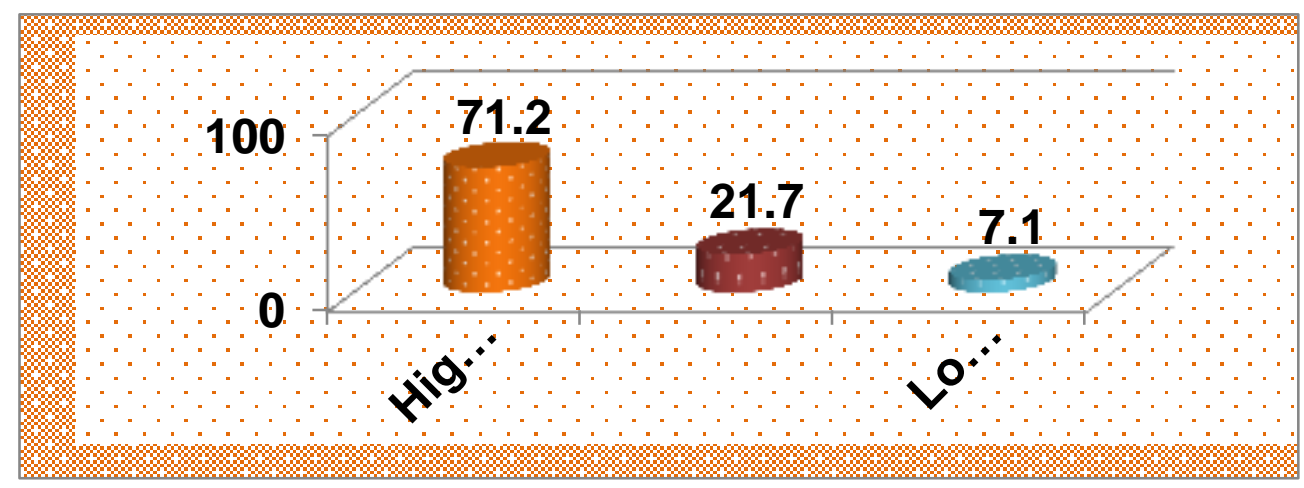

Figure (2): Total levels of academic satisfaction among studied nursing students

Table (3): Ranking with mean scores and standard deviation of academic satisfaction categories among nursing students $(n=309)$

\begin{tabular}{|l|l|l|l|l|l|}
\hline Academic satisfaction & $\begin{array}{l}\text { Maximum } \\
\text { score }\end{array}$ & Range & Mean \pm SD & Mean \% & Ranking \\
\hline Clinical teaching for teacher & 24 & $11-21$ & $20.36 \pm 3.25$ & 84.8 & 1 \\
\hline In-class teaching for teacher & 27 & $12-24$ & $22.39 \pm 3.85$ & 82.9 & 3 \\
\hline Program design and delivery & 18 & $6-15$ & $15.02 \pm 2.74$ & 83.5 & 2 \\
\hline Faculty support and resources & 15 & $5-9$ & $11.34 \pm 2.79$ & 75.6 & 4 \\
\hline Total & 84 & $42-80$ & $68.39 \pm 10.23$ & & \\
\hline
\end{tabular}


Table (4): Correlation between total perception levels toward teacher-student relationship and academic satisfaction among nursing students $(n=309)$

\begin{tabular}{|l||l|l||}
\hline Variable & \multicolumn{2}{|l|}{$\begin{array}{l}\text { Total perception levels toward teacher-student } \\
\text { relationship score }\end{array}$} \\
\cline { 2 - 3 } & $\mathbf{R}$ & P value \\
\hline Total academic satisfaction score & 0.736 & $0.000 * *$ \\
\hline
\end{tabular}

**A highly statistical significant correlation $(\mathbf{P} \leq \mathbf{0 . 0 0 1})$

\section{Discussion}

The findings of the present study illustrated that more than half of studied nursing students aged from 19 to 20 years old, about three quarters of them were female and from rural areas. Also, the vast majority of studied nursing students were single and about nearly two fifths of them from fourth year and had previous estimation were very good.

From the researcher point of view, this might be because most of student in faculty of nursing graduated from secondary school at the age of 18 , most of them were female who tend to achieve excellency in nursing career more than male and they are single because nursing students don't prefer marriage during study. Nursing students live around Benha city which is considered a rural area. Also, at the time of data collection, fourth year nursing students were the most expressive of their love to their college and the nursing profession which had a good previous estimation.

The findings of the present study revealed that the majority of studied nursing students had high perceived level, while the lowest percentage of them had low perceived level toward teacher- student relationship among nursing students. This might be due to most of the nursing students know their rights and colleges are currently within the scope of the quality of education that the nursing students were more conscious, the majority of the participants were young aged students who had positive perception for all things around them that makes them think positively. Also, it might be due to the competency of academic staff that enhancing teachers' ability to build good relationships with students.

This result was consistent with Kwak and Yi, (2016) who conducted study to determine relation of interpersonal relationship, clinical stress and satisfaction of clinical practice in nursing students and indicated that more than two thirds of the studied students reported good relation with their educators and give them more consideration. Also, this findings was matching with Brady, (2017) who conducted case study of student and teacher relationships and the effect on student learning in Rhodiland and reported that student perception of student and teacher relationship was higher.

\section{Similarly, Ciuladiene and} Raudeliunaite, (2015) who done study to assess whether relations between students and teachers are constructive at contemporary school and showed that the majority of studied nursing students were agreed about the relationship between students and teachers at 


\section{Nursing Students' Perception toward Teacher-Student Relationship and its Effect on their}

\section{Academic Satisfaction}

school are constructive and high. Conversely, this result was in disagreement with Omer, (2016) who conducted study to determine nursing students' perceptions of satisfaction and self-confidence with clinical simulation experience and stated that more than half of studied nursing students dissatisfied with the relation with their teachers.

Regarding ranking with mean scores and standard deviation of nursing students' perception toward domains of teacher-student relationship. The finding of the present study confirmed that the first ranking with highest mean score was nursing competency of teacher while, the last ranking with lowest mean score was teaching in classroom for teacher. From the researcher point of view this might be due to the nursing teacher has leadership qualities, showed interest in patients' health and welfare, which in turn showed enthusiasm toward nursing professional and respect patient integrity.

This result was supported by El-Gilany, El-Bastawesy, El-Sherbeny and Ibrahim, (2017) who conducted study in Egypt to assess undergraduate nursing students' perceptions of educational environment and found that the first ranking with highest mean score for teacherstudent relationship items related to the quality of nurse educators while the last ranking with lowest mean score was regarding teaching in classroom for teacher. Correspondingly, this finding in the same line with Salinda and Fernando, (2018) who done study at Sri Lanka to determine critical factors affecting students' satisfaction with higher education and mentioned that quality of university academic staff was the first ranking.
Conversely, this result was contraindicated with El Seesy, Hussein and Alzahrani, (2018) who conducted study at Alexandria University to determine undergraduate nursing students' perceptions of educational service quality and presented that the first ranking with highest mean score for teacher- student relationship was regarding lecturer room. Also, this result was disagreement with Varga, (2017) who done study to assess the effect of teacher-student relationships on the academic engagement of students and pointed out that the highest mean score were teachers' attitude and feedback.

The finding of the current study indicated that nearly three quarters of studied nursing students' had high satisfaction level, while the lowest percentage of them had low academic satisfaction level among studied nursing students toward teacher-student relationship. This might be due to the teacher is given sufficient guidance with knowledge and experience. Also the program designed facilities team work and relation among nursing student that facilities learning.

This result was parallel to Clifton and Stephen, (2016) who done study to assess the success of nursing students with bioscience courses at a regional university and clarified that the majority of studied nursing students' were agreed about teacher commitment and capability consider one important contributor to student academic satisfaction. Similarly, Sheikhi, Fallahi-Khoshknab and Rahgozar, (2019) who conducted study to assess the effect of integration of mentorship and peer education methods on the academic performance and academic satisfaction on nursing students and showed that more than half of the nursing 
students reported acceptable academic performance and academic satisfaction. Also, this finding was in agreement with Weerasinghe and Dedunu, (2017) who conducted study on University staff image and students' satisfaction in selected state universities in sirilanka and matched that the most of student were high satisfied related academic staff.

In contrary, this result was in disagreement with Gonzalez, Manzanares and Peinado, (2017) who done study to determine nursing students' satisfaction during their first year of study in a private university and confirmed that the majority of the nursing students' experienced frustrated feeling and low level of academic satisfaction. Also, this finding was disagreed with Navarro, Iglesias and Torres, (2015) who conducted study of a new management element for universities: satisfaction with the offered courses in Armenian and revealed that there was low student satisfaction level regarding higher educational facilities services.

The result of the current study showed that first ranking with highest mean score was regarding clinical teaching for teacher, while the last ranking with lowest mean score was related to faculty support and resources. From the researcher point of view this might be due to low resources and equipment of faculties that students need in the process of teaching and the library that facilities should be improved by purchasing necessary books, improving reading facilities and e-learning facilities. The number of computer labs and internet access points must increase with a proper technical assistance.
This result was congruence with Seada and Mostafa, (2017) who conducted study to determine students' satisfaction and barriers of e-learning course among nursing students and found that the first ranking was regarding quality of clinical nursing educators. Also, this finding was matching with Al Sebaee, Aziz and Mohamed, (2017) who done study to determine relationship between nursing students' clinical placement satisfaction, academic self-efficacy and achievement and showed that the last ranking related to adequate learning facilities. As well as, Weerasinghe and Dedunu (2017) who reported that there was direct and indirect impact of the quality of the academic staff on the student satisfaction levels through the university image in Sri Lankan contexts.

On the other hand this result was in contrast with the findings of Pathmini, Wijewardhena, Gamage and Gamini, (2018) who conducted study to assess impact of service quality on students' satisfaction in newly established public sector universities in Sri Lanka and clarified that quality of faculty facilities was the first rank impact on students' satisfaction.

The result of the current study revealed that there was highly statistical significant positive correlation between total perception levels toward teacher-student relationship score and total academic satisfaction $(\mathrm{p}<0.000)$ among nursing students'. This means that when teacher-student relationship increase, the academic satisfaction will increase also among nursing students' "this means positive effect". From the researcher point of view this might be due to teachers who act as a secure base are available, responsive and accepting of students' 


\section{Nursing Students' Perception toward Teacher-Student Relationship and its Effect on their}

Academic Satisfaction

needs-improve their students' commitment and satisfaction of the learning interests so, increasing nursing student's perception toward teacher-student relationship increased level of academic satisfaction among nursing students'.

This result was in agreement with ElGilany, El-Bastawesy, El-Sherbeny and Ibrahim, (2017) who found that there was a highly statistical significant positive correlation between educational relationships and total students' satisfaction. Also, the finding was matching with Seada and Mostafa, (2017) who found that there was a highly statistical significant positive correlation between relations among nursing students and education staff. Similarly, Javid, Babelan and Namvar, (2013) who done in Ardabil to determine the state of teacher-student verbal interactions during teaching process and its relationship with academic achievement of middle school students and mentioned that two-way communication between students and teachers play an important role in student's academic satisfaction.

\section{Corresponding, Hagenauera and} Volet, (2014) who conducted study to determine teacher-student relationship at university: an important yet under-researched field and demonstrated that teacher-student relationship should be regarded as a relevant construct in higher education as well as it clearly affects students' academic satisfaction. As well as, Omodan and Tsotetsi, (2018) who done study to determine student-teacher relationships as a panacea for students' academic performance in Nigeria secondary schools: An attachment perspective and reported that there is a significant relationship between student-teacher relationships and academic performance of students in secondary schools in Nigeria.

\section{Conclusion}

There was a highly statistically significant positive correlation between teacherstudent relationship score and total academic satisfaction score. Also, the majority of studied nursing students had high perceived while, the lowest percentage of them had low perceived level toward teacher-student relationship among nursing students. Additionally, the first ranking with highest mean score was related to nursing competency of teacher, while the last ranking with lowest mean score was regarding teaching in classroom for teacher.

Moreover, the finding revealed that, nearly three quarters of studied nursing students had high academic satisfaction level while, the lowest percentage of them had low academic satisfaction. Also, the first ranking with highest mean score related to clinical teaching for teacher, while the last ranking with lowest mean score was related to faculty support and resources.

\section{Recommendation}

- Increase awareness among nursing teacher/ faculty member by providing a series of workshops and training related to essential managerial skills needed to improve their leadership qualities and accept criticism.

- Develop classroom to facilitate and empower learning environment.

- Clarify nursing teachers' roles and responsibilities that related to relieve nursing student stress by pay attention to 
Heba Shaban Ahmed Ibrahim, Nermin Mohammed Eid and Ebtesam Saeed Ahmed

their feelings, characterized by a sense of humor and consider nursing students' individual difference.

- Help and enable nursing students' to deal with clinical nursing problems under supervision to become confident in their clinical skills.

- The nursing teacher take initiation, use suspense and attention grabbing methods media to increase motivation of nursing students'.

- Reapplication of the study on larger probability sample at different nursing faculties and universities in an effort to more fully understand the factors affecting on nursing students' academic satisfaction through teacher- student relationship.

\section{References}

Abd Elsamed, S. (1999). Teaching staff and nursing student perception about teacherstudent relationship patterns, published Master thesis, Faculty of Nursing, Alexandria University.

Al Sebaee, A., Aziz, A. and Mohamed, T. (2017). Relationship between nursing students' clinical placement satisfaction, academic self-efficacy and achievement. IOSR Journal of Nursing and Health Science, 6(02): pp. 101-112.

Andersson, K., Willman, A., SjostromStrand, A. and Borglin, G. (2015). Registered nurses' descriptions of caring: a phenomenographic interview study. BMC Nursing, pp. 14: 16.

Brady P. (2017). A case study of student and teacher and teacher relationships and the effect on student learning. Open Access Dissertations. Paper 266. Available at: https://digitalcommons.uri.edu/oa-diss/266.

Retrieved on 28/12/2018 at 12:30 p.m.

Cheng, M. (2016). Quality in higher education: Developing a virtue of professional practice. Springer. Available at: http://www.senaepublishers. Com Retrieved at 2/2/2019 at 9.30 a.m.

Ciuladienè, G. and Raudeliūnaitè, R. (2015). Whether relations between students and teachers are constructive at contemporary school? Procedia - Social and Behavioral Sciences, 191: pp. 2855 - 2860. Available online at www.sciencedirect.com.

Clifton, D. and McKillup, C. (2016). Why such success? Nursing students show consistently high satisfaction with bioscience courses at a regional university [online]. Australian Journal of Advanced Nursing, 33(3): PP. 21-28.

Dennison, S. (2010). Development and psychometric assessment of the undergraduate nursing Student academic satisfaction scale (UNSASS). The Journal of Nursing Measurement. 20(2):PP.75-89.

El Seesy, A., Hussein, G. and Alzahrani, E. (2018). Undergraduate nursing students' perceptions of educational service quality at Alexandria University, Egypt. Journal of Nursing Education and Practice, 8(1).

El-Gilany, A. H., El-Bastawesy, S., ElSherbeny, E. and Ibrahim, M. (2017). Undergraduate nursing students' perceptions of educational environment: a national study in Egypt. IOSR Journal of Nursing and Health Science, 6: pp. 66-71.

Gonzalez, R. (2016). The Impact and importance of positive student-teacher 
relationships. Empowered Learning Transformation Centers. Available at: https://www.eltcenters.com/eltc-blog. Retrieved at 20/6/2019 at 3 p.m.

González, S., Manzanares, L. and Peinado, A. (2017). Nursing students' satisfaction during their first year of study in a private university as regards the integration of ICTs. International Journal, 3(2): pp. 35-74.

Grugeon, E. and Garder, P. (2013). The art of storytelling for teachers and pupils: Using stories to develop literacy in primary classrooms. Routledge. www.iosrjournals.org, 1(13):17-29.

Hagenauer, G., and Volet, S. (2014). Student-teacher relationship at university: an important yet under-researched field. Oxford Review of Education, 40 (3):PP. 370-388.

Hirsch, D., Barlem, E. and Mendes, D. (2015). Predictive and associated factors with nursing students' satisfaction. Acta Paulista de Enfermagem 28:PP.566-572.

Hussain, M. N., Nawaz, B., Nasir, S., Kiani, N. and Hussain, M. (2013). Positive teacherstudent relationship and teachers' experience. Global Journal of Management and Business Research, 13(3):PP.1-5.

Javid, A., Babelan, Z. and Namvar,Y. (2013). A study on the state of teacher-student verbal interactions during teaching process and its relationship with academic achievement of middle school students in Ardabil. International Research Journal of Applied and Basic Sciences, 4(7): PP. 19091913.
Khawaji, Y., Tessema, T. and Nordin, S. (2016). The relationship between courses availability, student experience and college management which affecting student satisfaction with major curriculum: The application of structural equation modelling. In proceedings of the International Conference on Education towards Global Peace, (1): pp. 1-14.

Kwak, W. and Yi, E. (2016). Relation of interpersonal relationship, clinical stress and satisfaction of clinical practice in nursing students. Journal of the Korea AcademiaIndustrial cooperation Society, 17(2): pp. 147155.

Lyngdoh, B. (2017). Personal and school related factors affecting students' academic performance with special reference to higher secondary school laitumkhrah area, Shillong, Meghalaya (Unpublished Doctoral dissertation, Assam Bon Bosco University).

Mahdy, A. and Mahfouz, H. (2016). Evaluate the effectiveness of nurses' professional competence approach on their productivity in Medical- Surgical Units, Egyptian Journal of Health Care, 7(3): pp. 271-291.

Navarro, M., Iglesias, P. and Torres, R. (2015). A new management element for universities: satisfaction with the offered courses. International Journal of Educational Management, 19 (6): pp. 505 -526.

Omer, T. (2016). Nursing students' perceptions of satisfaction and self-confidence with clinical simulation experience. Journal of Education and Practice, 7(5): pp. 131-138. 
Heba Shaban Ahmed Ibrahim, Nermin Mohammed Eid and Ebtesam Saeed Ahmed

Omodan, I. and Tsotetsi, T. (2018). Student-teacher relationships as a panacea for students' academic performance in Nigeria secondary schools: An attachment perspective. Journal of Social Studies Education Research, 9 (4): PP. 82-101.

Ramos, M., Barlem, G., Lunardi, L., Barlem, L., Silveira, S. and Bordignon, S. (2015). Satisfaction with academic experience among undergraduate nursing students. Texto and Contexto-Enfermagem, 24(1): pp. 187195.

Resis, F. (2015). The relationship between teachers and students in the classroom: communicative language teaching approach and cooperative learning strategy to improve learning. Available at: http://vc.bridgew.edu/theses/22. Retrieved at $25 / 3 / 2019$ at 11 p.m.

Roberson, R. (2014). Understanding the development of legitimate teacher authority through the teacher-student relationship: A qualitative study. Shareok advancing Oklahoma scholarship, research and institutional memory, 358. Available at: http:// shareok.org./discover? Retrieved at 27/3/2020 at 4 p.m.

Salinda, W. and Fernando R. (2018). Critical factors affecting students' satisfaction with higher education in Sri Lanka. 26 (1): pp.115-130. Available at: https://www.researchgate.net/publication/331 374737

Singh, P. and Badugu, D. (2017). Investigating the impact of customer relationship management on customer satisfaction with reference to the hotel industry. International Journal of Business and Management Invention, 6(8): pp. 72-76.

Singh S. (2012). Education systems and academic satisfaction: a study on rural and urban students of traditional vs open education system in India. Turk Online J Dist Educ, 13(3): pp. 390-406.

Seada, A. and Mostafa, F. (2017). Students' satisfaction and barriers of E-learning course among nursing students, Mansoura University World Journal of Nursing Sciences, 3 (3): pp. 170-178.

Shafer, J. (2015). Pre service teacher understanding and implementation of caring teacher-learning student relationships. (Unpublished Doctoral dissertationUniversity of Nebraska-Lincoln).

Sheikhi, M., Fallahi-Khoshknab, M. and Rahgozar, M. (2019). The effect of integration of mentorshiping and peer education methods on the academic performance and academic satisfaction in Nursing PhD Students. Journal of Nursing Education, 7(5): pp. 52-58.

Telef, B., Arslan, G., Mert, A. and Kalafat, S. (2015). The mediation effect of school satisfaction in the relationship between teacher support, positive affect and life satisfaction in adolescents. Educational Research and Reviews, 10(12): pp. 1633.

Varga, M. (2017). The effect of teacherstudent relationship on the academic engagement of students. Graduate Programs in Education. Available at: https://mdsoar.org/bitstream/handle/Varga Meagan Paper. Pdf? Retrieved at 31 /3/2019 at 7 A.m. 
Weerasinghe, I. and Dedunu, H. (2017). University staff, image and students' satisfaction in selected state universities. IOSR Journal of Business and Management (IOSR-JBM), Vol. 19 (5): pp. 34-37.
Yamane, T. (1967). Statistics an Introductory Analysis. 2nd Edition, Harper and Row, New York. [Citation Time(s):2] 


\section{إدراك طلاب التمريض تجاه العلاقة بين المعلم والطالب وتأثيره على رضائهم الاكاديمي هبه شعبان احمد - نرمين عحم عيد- ابتسام سعيد احمد}

العلاقة بين المعلم و الطالب مهمة جدا للتعليم الجيد ولا يحدث أي تعلم بدون علاقة قوية تمكن المعلمين من التأثير على كل جانب من جوانب طلابهم. لذلك هدفت هذه الدراسة إلى تحديد ادر اك طلاب التمريض تجاه العلاقة بين المعلم والطالب وتأثيره على رضائهم الاكاديمي. وقد أجريت الدراسة بكلية التمريض جامعة بنها على عينة عشو ائية من جميع طلاب التمريض الجامعيين المسجلين في الفرقة الثانية والثالثة والرابعة في العام

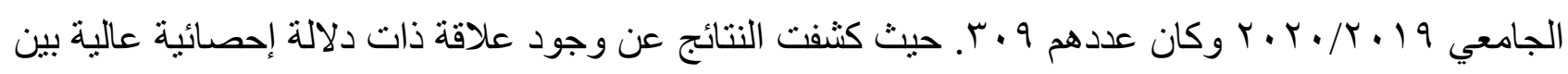
مستويات الادراك الكلي نحو درجة العلاقة بين المعلم والطالب و الرضا الاكاديمي الكلي بين طلاب التمريض . كما أوصت الدراسة بضرورة توضيح أدوار ومسؤليات معلمي التمريض التي تتعلق بتخفيف اجهاد طالب التمريض من خلال الاهتمام بمشاعر هم والنظر في الفروق الفردية لطلاب التمريض. 